International Journal of Agriculture, Environment and Bioresearch

Vol. 5, No. 04; 2020

ISSN: $2456-8643$

\title{
PHYSICAL-CHEMICAL QUALITY OF UROchloa GRASSES IN DIFFERENT PHENOLOGICAL STAGES
}

\author{
Maria de los Angeles Maldonado Peralta ${ }^{1}$, Adelaido Rafael Rojas Garcia ${ }^{1 *}$, Filiberto Magadan Olmedo ${ }^{1}$, \\ Mariela Pinacho Martinez ${ }^{2}$, Herminio Aniano Aguirre ${ }^{2}$ and Lauro Gasga Perez ${ }^{2}$ \\ ${ }^{1}$ Universidad Autónoma de Guerrero, Facultad de Medicina Veterinaria y Zootecnia No 2. Cuajinicuilapa, Guerrero, \\ México \\ ${ }^{2}$ Instituto Tecnológico Nacional de México, Campus Instituto Tecnológico de Pinotepa, Pinotepa Nacional, Oaxaca, \\ México
}

https://doi.org/10.35410/IJAEB.2020.5536

\begin{abstract}
The objective was to evaluate the physical-chemical quality of hybrids Urochloa (Insurgent, Piata and Signal) at different phenological stages, in the dry tropics. The evaluated variables were: total forage yield and per components, intercepted radiation, plant height and crude protein per component. A complete blocks design was used to the random with arrangement in divided plots and four repetitions, with the procedure PROC GLM of SAS. In the three grasses, the best total dry matter yield was obtained at 49 days of regrowth, with $6732 \mathrm{~kg}$ DM ha-1 in the Insurgent grass, Piata with 3320 and Signal presented $2675 \mathrm{~kg}$ DM ha-1; the leaf component presented a higher percentage of crude protein, at 14 days, reaching 22, 21 and $21 \%$ for the Piata, Insurgent and Signal grasses, respectively $(\mathrm{P}=0.05)$. As the regrowth increased, the yield of total dry matter, leaf and plant height increased, on day 49 the decline began; however, the stem component and senescence increased until day 56. The percentage of intercepted radiation of $95 \%$ was on day 42 of regrowth, considering this the optimal cutting moment.
\end{abstract}

Keywords: Urochloa, forage accumulation, crude protein.

\section{INTRODUCTION}

The demand for food worldwide by the growing population demands changes in the agricultural field; So much that, by 2050 production must increase by $60 \%$, using land that is already being exploited, producing more with less natural resources (Gerber et al. 2013). Grasses and forages production use $80 \%$ of agricultural soils and $8 \%$ of water; therefore, the sustainability of livestock systems requires adapting and facing climate change (Morales-Velasco et al. 2016; Steinfeld et al. 2006), seeking alternatives that improve production and using biological technologies that affect less.

The use of technological packages based on genetic improvement of native grasses species; It has allowed the use of new varieties or genotypes with better production (Morales-Velasco et al. 2016) and protein contents above 9\% (Poppi and Mclennan, 1995; Rojas et al. 2018); that are alternatives for periods of low water, where the availability of native forages decreases drastically, having losses in weight gain, milk production, and soil erosion (Barhona et al. 2014; Mayren -Mendoza et al. 2018). 
All forage species, achieve a better biomass production when they are cultivated where temperatures are optimal (McKenzie et al. 1999; Muñoz-Gonzáles et al. 2016); in addition, it is demonstrated that the pastures with higher development efficiency have better nutritional quality (Cid et al. 2008). Studies show that in hybridsBrachiaria now Urochloa the crude protein content ranges between 8 and 18\% (Dairy Australia, 2005) and between 7 and 19\%, depending on the production conditions (fertilization, irrigation, rain, dry, etc.), from the harvest season, it is also common that in all forage species as age increases, the nutritional contents are reduced (Euclides, 2001; Gómez et al. 2000; Pérez-López and Afanador-Téllez, 2017). Rojas et al. (2018), evaluated the Cobra grass (Brachiaria HYBRID BR02 /1794) and found that, at 35 days of regrowth, at an intensity of $15 \mathrm{~cm}$ it presents $1200 \mathrm{~kg} \mathrm{DM} \mathrm{ha}^{-1}$ of dry matter in the leaf, with $21.01 \%$ crude protein. The morphological quality also increases when the plants develop in the right conditions, in rainy season the Brachiarias fertilized with Nitrogen considerably increase the height (Fagundes et al. 2006; Pérez-López and Afanador-Téllez, 2017), internode elongation, increase in the rate of leaf apparition and therefore better soil coverage (Santos et al. 1998).

Under this premise, research is required on improved species that generate sustainable alternatives to maintain the productivity of livestock systems; Because low production is associated with inefficient management of dry matter available in grasses; therefore, the objective is to evaluate the physical-chemical quality of hybridsUrochloa (Insurgent, Piata and Signal) at different phenological stages, in the dry tropics.

\section{MATERIALS AND METHODS}

Location of the experimental area: This research was carried out in the experimental unit of the Instituto Tecnológico de Pinotepa, located at kilometer 26 of the Pinotepa Nacional highway, Oaxaca - Acapulco, south of the town of San José Estancia Grande, Oaxaca, in the period from August to December 2017 and laboratory analyzes in the same experimental unit from January to June 2018.

It is located at $16^{\circ} 22^{\prime}$ north latitude and $98^{\circ} 13^{\prime}$ west longitude, with a height of 60 masl according to the Köeppen climate classification, it presents an Aw (w) ig climate, it corresponds to a sub-humid warm climate (García, 2004), with a summer rainfall regime. The pluvial precipitation is in a range of $1000-1500 \mathrm{~mm}$ per year with a rainy period from June to September with 8 months of drought, with an average temperature of $26-28{ }^{\circ} \mathrm{C}$.

Parcel management: Planting was carried out on August 10, 2017, with pure viable seed from three grasses of the Urochloa genus. The sowing method was direct, at a distance between furrow and furrow of $50 \mathrm{~cm}$ and between plants of $20 \mathrm{~cm}$. Four $10 \times 5 \mathrm{~m}$ plots were planted, being experimental units for each grass. These are in turn in eight areas, in order to evaluate a growth analysis with eight regrowth ages. The soil with a sandy clay texture, $\mathrm{pH} 4.8$ to 5.0, deficient in organic matter. The weed was controlled manually with the help of a hoe, two nitrogen fertilizations were carried out with urea (46-00-00), the first was done on September 28 and the second was on October 17, 2017. Before starting the analyzes of growth on October 20, 2017, a homogenization cut was made at a height of $10 \mathrm{~cm}$ in all the experimental plots. Aid irrigation was carried out by the drip method to help the good growth of the pastures every 3 days.

Variables evaluated 
Total and component forage accumulation: In each grass after the uniformization cut, every seven days two $50 \times 50 \mathrm{~cm}$ squares were cut in each experimental plot at $10 \mathrm{~cm}$ height, randomly selected; the forage was separated into its leaf, stem and senescence components. It was washed, and it was deposited in a forced air stove at $55^{\circ} \mathrm{C}$ until constant weight, recording the weight to estimate the dry matter per hectare, at the different cutting ages.

Intercepted radiation: One day prior to each cut, five repetition radiation readings were taken at random with the wooden meter method described by Rojas et al. (2016) in each experimental unit. The readings were made at approximately 1:00 p.m. The procedure consisted of placing the ruler on the surface of the ground (under the canopy), facing south-north, and immediately afterwards, the shaded centimeters were counted, which represented the percentage of radiation intercepted by the vegetal canopy.

Plant height: After the homogenization cut, the average height per plant was estimated weekly, one day before the evaluation, taking 20 readings at random in each experimental plot. For this, a $100 \mathrm{~cm}$ graduated ruler was used and the height was taken into account in the morphological component with the highest height.

Crude protein: The leaf, stem and complete plant of each sample were obtained separately from the morphological composition sample, they were analyzed in triplicate and the nitrogen content was determined and, multiplied by the constant 6.25 , obtaining crude protein (AOAC, 2005).

Statistical analysis: The data was analyzed using a completely randomized block design with arrangement in divided plots and four replications, the procedure used was PROC GLM from SAS (2011), where the cuting frequency effects were considered as fixed. The multiple comparison of means of the treatments was carried out using the Tukey test $(\alpha=0.05)$.

\section{RESULTS AND DISCUSSION}

\section{Total and component forage accumulation}

The total dry matter yield and by component are observed in Figure 1 of the Insurgent, Piata and Signal grasses by varying the phenological state of the plant. In all three grasses, the yield in the first days of growth was slow and then accelerated to subsequently decrease. The highest total dry matter yield was obtained in the three grasses, at 49 days of regrowth with $6732 \mathrm{~kg} \mathrm{DM}$ ha $^{-}$ ${ }^{1}$ in the Insurgent grass followed by Piata and the lowest Signal with 3320 and $2675 \mathrm{~kg} \mathrm{DM} \mathrm{ha}^{-1}$, respectively $(\mathrm{P} \leq 0.05)$.

Likewise, the highest proportion of leaf was reported on day 49 with 4721,2512 and $1420 \mathrm{~kg}$ $\mathrm{DM} \mathrm{ha}^{-1}$, respectively for the Insurgent grass, Piata and Signal grass (Figure 1; $\mathrm{P} \leq 0.05$ ), and later begin to decline as the leaves in the lower layers were senescing (Calzada et al. 2013; Rojas et al. 2018; Maldonado et al. 2019). They consignhigher senescence at a longer regrowth time for being below the compensation point of lightuntil the leaves continually die as happened in this investigation, initiating senescence on day 35 and increasing continuously until day 56, having the Insurgent grass and Piata the highest and lowest senescence with 888 and $128 \mathrm{~kg}$ DM ha $^{-1}$, respectively $(\mathrm{P} \leq 0.05)$. 
Vol. 5, No. 04; 2020

ISSN: $2456-8643$
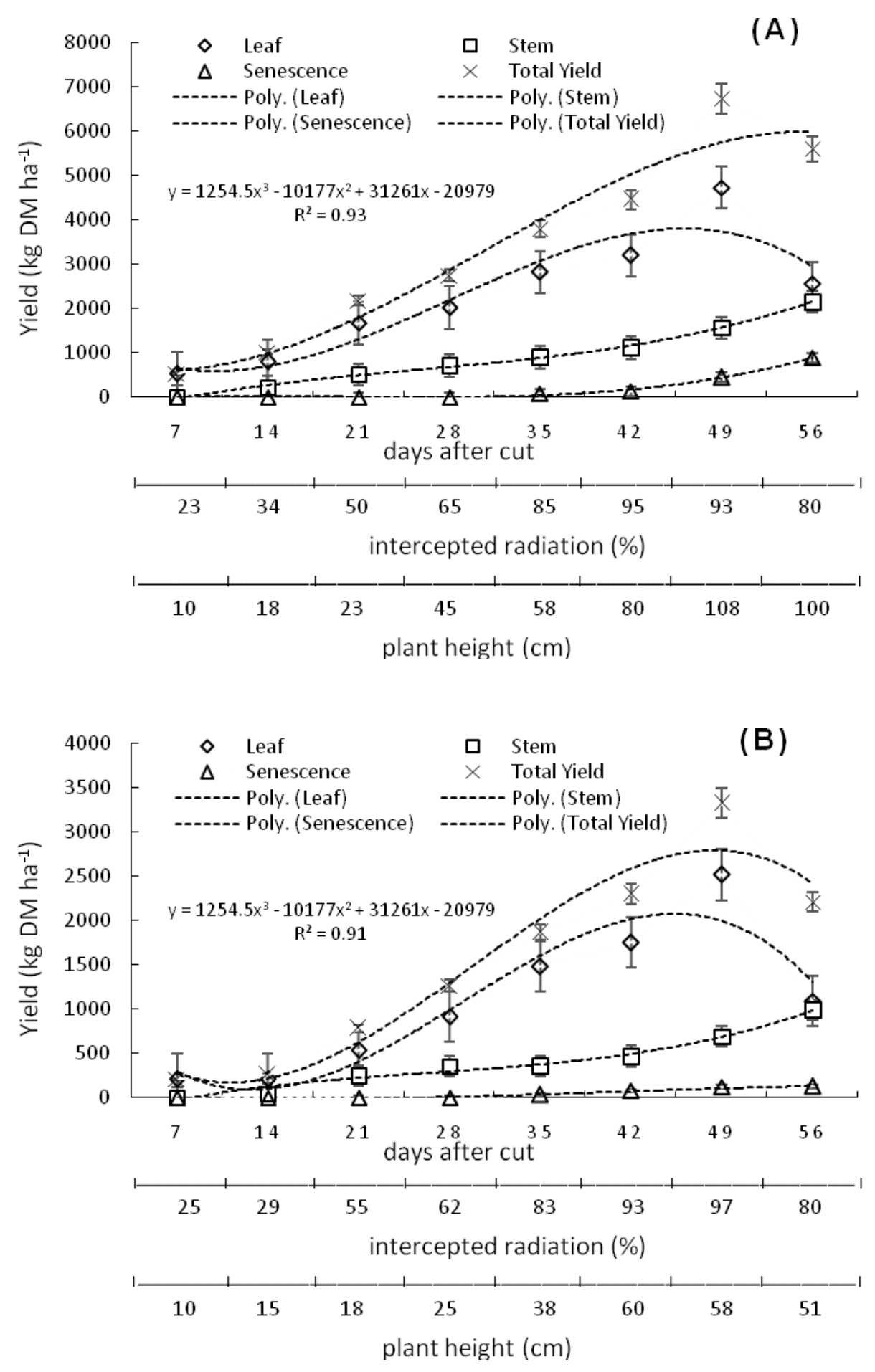
Vol. 5, No. 04; 2020

ISSN: $2456-8643$

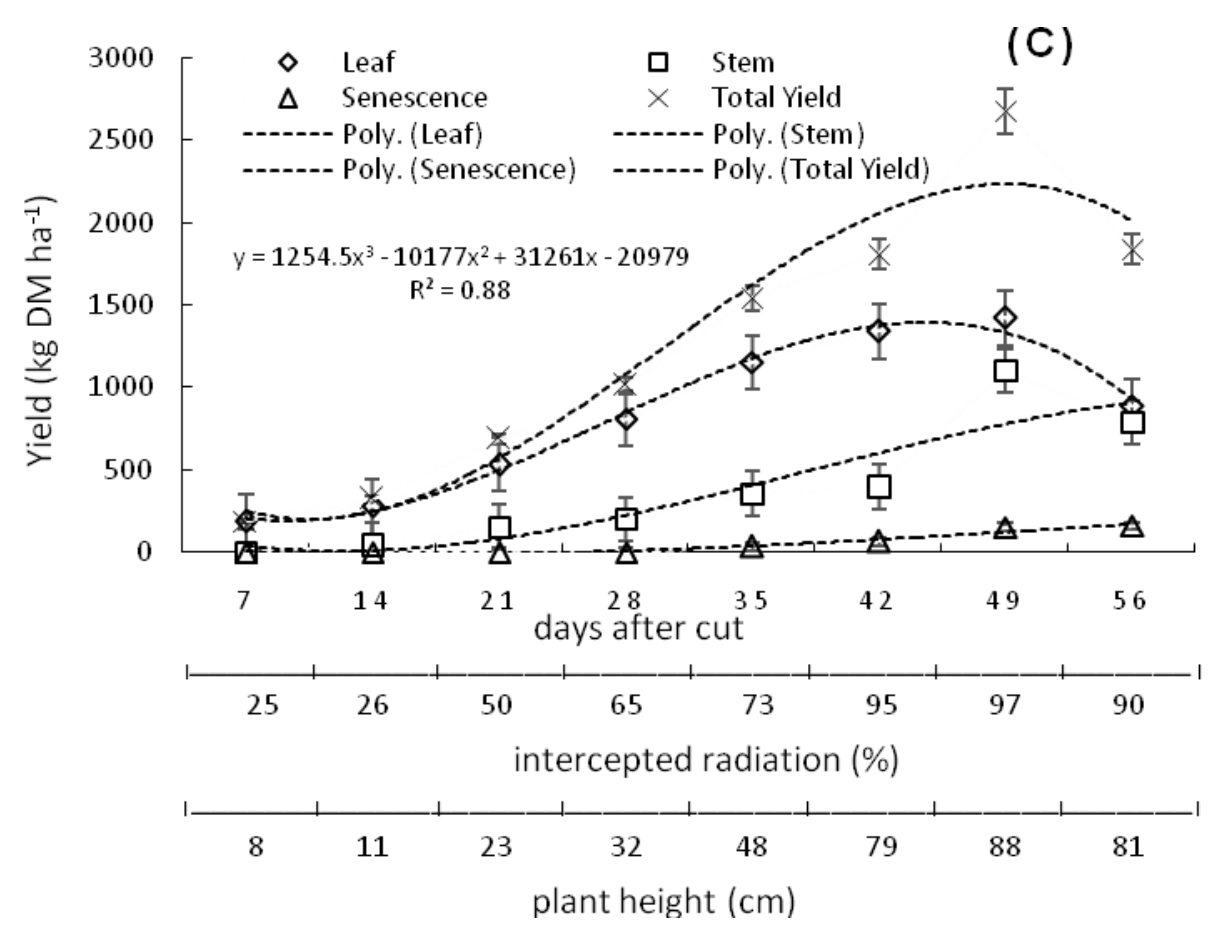

Figure 1. Total and component yield, intercepted radiation and plant height of grass Insurgent (A), Piata (B) and Signal (C) from hybridUrochloa in different phenological stages.

In the case of the stem component at the beginning of the evaluation, the contribution of dry matter was null, however, It was increasingaccordingelapsedthe evaluation period until day 56, with the highest yield being the Insurgent grass followed by Piata and Signal with 2147, 989 and $787 \mathrm{~kg} \mathrm{DM} \mathrm{ha}^{-1}$, respectively $(\mathrm{P} \leq 0.05)$. Similar trend to those of this research are reported by several researchers (Velasco et al. 2001; Rueda et al. 2016; Wilson et al. 2017) in growth analysis of different grasses where the highest yield is obtained in the sixth week regrowth tending to decrease. The higher yield reported at 49 days of regrowth could be due to the trend growth that grasses have to a slow growth, accelerated growth and with a trend to decrease as other researchers report (Rojas et al. 2016; Cruz et al. 2017a) In another investigation of the Cobra grass (hybrid Urochloa) Rojas et al. (2018) obtained the highest dry matter yield at 56 days at a defoliation intensity of $15 \mathrm{~cm}$ with $2550 \mathrm{~kg} \mathrm{DM} \mathrm{ha}^{-1}$, related to this investigation in Piata and Signal grass.

Leaf, stem, senescence changes are variable and are influenced by the time of year, planting density, associations and monoculture (Rojas et al. 2016; Maldonado et al., 2019). On the other hand, Juskiw et al. (2000) mention that in the advanced physiological stages the yield of stem, senescence and spike is increased, decreasing the leaf, due in part to the translocation of nutrients from the leaves that results in the senescence and death of this component for filling grain, which in this case was just starting.

\section{Intercepted radiation}

Figure 1 shows the intercepted radiation from the Insurgent, Piata and Signal grasses by varying the phenological state. As the cutting frequency increases, the radiation intercepted in the three grasses increases until it reaches a maximum point and tends to decrease $(P=0.05)$. The grass 
Insurgent and Signal reached on day 42 the radiation of $95 \%$ optimal cutting time according to several researchers (Da Silva and Nascimento, 2007), since this is when the best structural characteristics of the meadow are found and with the highest quality. However, the highest radiation was found at the highest cutting frequency at 49 days in Piata and Signal with $97 \%$ of radiation, which shows the trend of leaf decrease and stem increase and senescence supported by other researchers (Da Silva and Hernández-Garay, 2010) in tropical grasses. Therefore, where it is recommended to harvest the forage is when it reaches $95 \%$ of radiation intercepted in this case with the conditions and management given on day 43 after regrowth on average in the three grasses.

In this regard, Maldonado et al. (2019) reinforce the mentioned of harvesting the forage when it reaches $95 \%$ of intercepted radiation since the greatest amount of green leaves is found; For their part, other researchers (Mattera et al., 2013; Rojas et al. 2016) consign that these results are achieved when the density of plants is competitive not less than 30 plants per $\mathrm{m}^{-2}$. In their investigations, Federick and Bauder, (1999) and Da silva and Hernández-Garay, (2010) report the ability of different grasses to capture solar radiation and depends on the number of plants, cutting frequency and intensity and the environmental conditions at which that were exposed during their growth.

\section{Plant height}

Figure 1 shows the height of the Insurgent, Piata and Signal grasses by varying phenological states. Independently of the grass, the height increased as well as the radiation as the evaluation period passed $(\mathrm{P}=0.05)$. The highest plant height was reported in the Insurgent grass at 49 days with $108 \mathrm{~cm}$ coinciding with the highest total forage yield $(\mathrm{P}=0.05)$. Secondly, was the Signal grass again at 49 days of regrowth with $88 \mathrm{~cm}$ of height and finally the Piata grass on day 42 with $60 \mathrm{~cm}(\mathrm{P}=0.05)$; being closely related to the total yield, higher contribution of the sheet and intercepted radiation of $95 \%$. Similar results in tropical grasses obtained Calzada et al. (2014) and Rojas et al. (2018) a higher height combined with a higher yield of total dry matter and intercepted radiation up to a certain point to begin to decline.

\section{Crude protein}

Table 1 shows the percentage of crude protein of the leaf, stem and complete plant of three grasses of the genus Urochloa.The opposite of yield, height and radiation protein content radiation decreases as the evaluation period progresses in the three grasses and plant components. The leaf component was the one that obtained the highest percentage of crude protein in the three grasses, reporting on day 14 the highest percentage with 22, 21 and $21 \%$ of crude protein for the Piata, Insurgent and Signal grasses, respectively $(\mathrm{P}=0.05)$; on day 56 , the lowest percentage of crude protein in the leaf was obtained with 12, 14 and 14\% for Piata, Insurgent and Signal, respectively $(\mathrm{P}=0.05)$. In the stem component, the highest percentage occurred on day 14 with 15, 15 and $13 \%$ crude protein for Insurgent, Signal and Piata, respectively $(\mathrm{P}=0.05)$. Finally, the entire plant exhibited an average of $18 \%$ crude protein in the three grasses, decreasing its crude protein content to $12 \%$ on day 56. 
Table 2. Crude protein $(\%)$ by component and entire plant of three grasses of the Urochloa genus in a growth curve.

\begin{tabular}{|c|c|c|c|c|c|}
\hline \multirow{2}{*}{ Grasses } & \multicolumn{5}{|c|}{ Days after cut } \\
\hline & 14 & 28 & 42 & 49 & 56 \\
\hline \multicolumn{6}{|c|}{ Leaf } \\
\hline Insurgent & $21 \mathrm{a}$ & $16 \mathrm{~b}$ & $16 \mathrm{~b}$ & $15 b c$ & $14 \mathrm{c}$ \\
\hline Piata & $22 \mathrm{a}$ & $15 \mathrm{c}$ & $16 \mathrm{~b}$ & $15 \mathrm{c}$ & $12 \mathrm{~d}$ \\
\hline Signal & $21 \mathrm{a}$ & $16 \mathrm{~b}$ & $16 \mathrm{~b}$ & $16 \mathrm{~b}$ & $14 \mathrm{c}$ \\
\hline \multicolumn{6}{|c|}{ Stem } \\
\hline Insurgent & $15 \mathrm{a}$ & $13 b$ & $12 \mathrm{c}$ & $14 \mathrm{~b}$ & $9 \mathrm{~d}$ \\
\hline Piata & $13 \mathrm{a}$ & $13 \mathrm{a}$ & $12 \mathrm{ab}$ & $12 \mathrm{ab}$ & $9 \mathrm{~b}$ \\
\hline Signal & $15 \mathrm{a}$ & $13 \mathrm{c}$ & $14 \mathrm{~b}$ & $12 \mathrm{~d}$ & $11 \mathrm{e}$ \\
\hline \multicolumn{6}{|c|}{ Entire plant } \\
\hline Insurgent & 18 & $15 b$ & $14 \mathrm{~b}$ & $14 \mathrm{~b}$ & $12 \mathrm{c}$ \\
\hline Piata & $17 \mathrm{a}$ & $14 \mathrm{~b}$ & $14 \mathrm{~b}$ & $14 \mathrm{~b}$ & $11 \mathrm{c}$ \\
\hline Signal & 18 & $15 b$ & $15 \mathrm{~b}$ & $14 \mathrm{c}$ & $12 \mathrm{~d}$ \\
\hline
\end{tabular}

$a b c=$ Averages with the same lowercase literal in the same row, are not different $(\mathrm{P}=0.05)$.

The same trends and crude protein values were reported by Castro-Salas (2014) in a hybridUrochloain the leaf component, decreasing the percentage of protein as the regrowth time increased with a content of 17.4 and $11.8 \%$ of crude protein on day 7 at 49 regrowth in Mulato II. On the other hand, Rojas et al. (2018) in Cobra grass (hybrid Urochloa) obtained in leaf and stem similar results to those of this study, reporting on day $21,20 \%$ of protein in leaf and $13 \%$ in stem and decreasing until day 63 with 7 and $4 \%$ of protein in leaf and stem, respectively.

\section{CONCLUSION}

As the age of the regrowth increased, the yield of total dry matter and leaf and plant height increased until day 49, later, it begins to decline; however, the stem and senescence component were increasing until day 56 . Where the percentage of intercepted radiation is $95 \%$ is on day 42 
of regrowth. In the leaf, stem and complete plant components, crude protein was higher in the younger phenological stages, decreasing as the age of the plant increased. A longer evaluation time is recommended and at different times of the year to broaden the decision landscape.

\section{REFERENCES}

AOAC. (2005) Official Methods of Analysis. Edition 18. Association of Official Analytical Chemists. Washington, EE.UU. 1928 p.

Barahona R., S. M. Sánchez, E. Murgueitio y J. Chará (2014) Contribución de la Leucaena leucocephala Lam (de Wit) a la oferta y digestibilidad de nutrientes y las emisiones de metano entérico en bovinos pastoreando en sistemas silvopastoriles intensivos. Revista Carta Fedegán 140(1): 66-69.

Calzada M. J. M.,Q. J. F. Enríquez, G. A. Hernández, J. E. Ortega y P. S. I. Mendoza(2014) Análisis de crecimiento del pasto maralfalfa (Pennisetumsp.) en clima cálido subhúmedo. Revista Mexicana de Ciencias Pecuarias 5(2): 247260.http://www.scielo.org.mx/pdf/rmcp/v5n2/v5n2a9.pdf

Cid M. S, M. C. Ferri, A. M. Brizuela y O. Sala (2008)Structuralheterogeneity and productivity of a tallfescue pasture grazedrotationallybycattle at fourstockingdensities. JapaneseSocietyGrasslandScience $\quad 54: \quad 9-16$. file:///C:/Users/Maria\%20de\%20los\%20Angeles/Downloads/cid2008.pdf

Cruz H.A., G. A. Hernández,I. E. Aranda,C. A. J. Chay,Q. C. Márquez,G. A. R. Rojas yV. A. Gómez (2017) Nutritive value of Mulato grass under different grazing strategies. Ecosistemas y RecursosAgropecuarios 4(10): 65-72. http://www.redalyc.org/pdf/3586/358649676007.pdf

Da Silva S. C. yA. Hernández-Garay(2010) Manejo de pastoreo en praderas tropicales. Forrajes y su impacto en el Trópico. lera (ed). México. Universidad Autónoma de Chiapas, México p. 43-62.

Da Silva S. C. doJ. D. D. Nascimento (2007)Avanços na pesquisa com plantas forrageirastropicaisempastagens: características morfofisiológicas e manejo do pastejo. Revista Brasileira de Zootecnia 36: 122-138.

http://www.scielo.br/pdf/rbz/v36s0/14.pdf

Dairy Australia (2005)AustralianDairyIndustry in Focus: Dairy AustraliaDeliveringforthedairyindustry [Internet]. Southbank Victoria (AUS): Dairy Australia; [citado el 25 de marzo de 2020]. https://www.slideblast.com/infocus2005p2aindd_59b3a6451723dd8b07a6789d. html.

Euclides V. P. B. (2001)Produção animal em sistema intensivo combinado de pastagenstanzânia e braquiárias na região dos Cerrados: Programa Produção Animal. Subprojeto 06.0.99.188.01. $\begin{array}{llllll}\text { Campo } & \text { Grande } & \text { (BR): } & \text { Embrapa-Cnpgc } & \text { p. } & 13 .\end{array}$ http://www.scielo.br/scielo.php?script=sci_nlinks\&ref=000123\&pid=S15163598201000070000400013\&lng=pt

Fagundes J. L., M. D. Fonseca, C. Mistura, R. Morais, C. M. T. Vitor, A. J. Gomide, D. J. R. Nascimento, R. D. Casagrande e L. Costa (2006) Características morfogênicas e estruturais do capim-braquiária empastagemadubadacomnitrogênioavaliadasnasquatroestações do ano. RevBrasZootec 35(1): 21-29. http://www.scielo.br/pdf/rbz/v35n1/28338.pdf 
Federick J. R. andP.J. Bauer (1999) "Physiological and Numerical Components of Wheat Yield", in Satorre HE. y GA. Slafer (eds). Wheat, Ecology and Physiology of Yield Determination. Foot Products Press, Nueva York.

García E. (2004) Modificaciones al Sistema de Clasificación Climática de Koppen. 4 (ed). Universidad Nacional Autónoma de México. México, D. F. 217 p.

Gerber P. J., H. Steinfeld, B. Henderson, A. Motter. C. Opio, J. Dijkman, A. Falcucci and G. Tempio (2013) Hacer frente al cambio climático a través de la ganadería-Evaluación global de las emisiones y las oportunidades de mitigación. Organización de las naciones unidas para la alimentación y la agricultura (FAO). Roma (Italia) p. 154. http://www.fao.org/3/a-i3437s.pdf Gómez M. M., E. J. Velásquez, W. J. Miles y F. T. Rayo (2000) Adaptación de Brachiaria en el Piedemonte amazônico colombiano. Pasturas Tropicales 22(1): 19-25.

Juskiw P.E., J. H. Helm and D. F. Salmon (2000)Postheading biomass distribution for monocrops and mixtures of small grain cereals. CropScience 40(1): 148-158.

MatteraJ.; L. A. Romero, A. L. Cuatrin, P. S. Cornaglia and A. A. Grimoldi(2013) Yield components, light interception and radiation use efficiency of lucerne (Medicago sativaL.) in response to row spacing. European Journal of Agronomy 45:87-95. DOI: 10.1016/j.eja.2012.10.008

Mayren-Mendoza F. de J., A. R. Rojas-García, M. de los A. Maldonado-Peralta, O. Ramírez-Reynoso, J. Herrera-Pérez, N. Torres-Salado, P. Sánchez-Santillán, M. B. BottiniLuzardo y A. Hernández-Garay (2018) Comportamiento productivo de ovinos pelibuey en pastoreo suplementados con follaje de Guazumaulmifolia Lam. Agroproductividad 11(5): 2933.https://revista-agroproductividad.org/index.php/agroproductividad/article/view/367

Maldonado P. M. A., G. A. R. Rojas,S. P. Sánchez,L. M. B. Bottini,S. N.Torres,R. J. Ventura,C. S. Joaquín yG. M. J Luna (2019) Análisis de crecimiento del pasto Cuba OM-22 (Pennisetumpurpureum X Pennisetumglaucum) en el trópico seco. Agroproductividad 12 (8): 17-22.

http://revista-agroproductividad.org/index.php/agroproductividad/article/view/1445/1175

McKenzie B. A., P. D. Kemp, D. J. Moot, C. Matthew and R. L. Lucas (1999) Environmental effects on plant growth and development. In: New Zealand Pastures and Crop Science. Oxford University Press. p. 323. https://www.worldcat.org/title/new-zealand-pasture-and-cropscience/oclc/688658809

Morales-Velasco S., N. J. Vivas-Quila y V. F. Teran-Gomez (2016) Ganadería eco-eficiente y la adaptación al cambio climático. Biotecnología en el Sector Agropecuario y Agroindustrial 14 (1): 135-144. http://www.scielo.org.co/pdf/bsaa/v14n1/v14n1a17.pdf

Muñoz-González J. C., M. Huerta-Bravo, B. A. Lara, S. R. Rangel y A. J. L. de la Rosa (2016) Producción de materia seca de forrajes en condiciones de Trópico Húmedo en México. Revista Mexicana de Ciencias Agrícolas Pub. Esp. (16): 3329-3341. http://www.scielo.org.mx/pdf/remexca/v7nspe16/2007-0934-remexca-7-spe16-3329-en.pdf

Pérez-López $O$ y G. Afanador-Téllez (2017) Comportamiento agronómico y nutricional de genotipos de Brachiariaspp. Manejados con fertilización nitrogenada, solos y asociados con Puerariaphaseoloides, en condiciones de la Altillanura Colombiana. Rev. MedVetZoot 64(3): 52-77. http://www.scielo.org.co/pdf/rfmvz/v64n3/0120-2952-rfmvz-64-03-00052.pdf

Poppi D. P and R. S. Mclennan (1995)Protein and energyutilizationbyruminants at pasture. Journal of Animal Science 73(1): 278-290. https://doi.org/10.2527/1995.731278x 
Rojas G. A. R., S. N. Torres, P. M. A. Maldonado, S. P. Sánchez, B. A. García, P. S. I. Mendoza, V. P. Álvarez, P. J. Herrera y G. A. Hernández(2018) Curva de crecimiento y calidad del pasto cobra (Brachiaria Hibrido BR02/1794) a dos intensidades de cortes. Agroproductividad 11 (5): 34-38.

http://revista-agroproductividad.org/index.php/agroproductividad/article/view/368/256

Rojas G.A.R., G. A. Hernández,C. A. R. Quero,R. J. D. Guerrero,W. Ayala,R. J. L. Zaragoza yL. C. Trejo (2016) Persistencia de Dactylisglomerata L. solo y asociado con Lolium perenne L. y Trifoliumrepens L. Revista Mexicana de Ciencias Agrícolas 7(4): 885-895. http://www.scielo.org.mx/pdf/remexca/v7n4/2007-0934-remexca-7-04-00885.pdf

Rueda J. A.,J. E. Ortega, G. A, Hernández, Q. J. F. Enríquez, R. J. D. Guerrero and C. A. R. Quero (2016) Growth, yield, fiber content and lodging resistance in eight varieties of Cenchrus purpureus (Schumach.) Morrone intended as energy crop. Biomass and Bioenergy 88: 59-65. https://doi.org/10.1016/j.biombioe.2016.03.007Get rights and content SAS(2011) The SAS 9.2 for Windows. SAS Institute Inc. Cary, North Carolina. USA. Santos D., N. Curi, F. M. Martins, E. A. Ricardo, F. A. Da Cruz e T. W. Geraldes (1998)Perdas de solo e produtividade de pastagens nativas e melhoradassob diferentes práticas de manejo. Pesq. Agropec. Bras., Brasilia 33(2): 183-189. https://pdfs.semanticscholar.org/9d66/380b8a7e19eaa25cf00f595cb95adc8e4b6c.pdf

Steinfeld, H., T. Wassenaar and S. Jutzi (2006)Livestockproduction systems in developingcountries: status, drivers, trends Rev. sci. tech. Off. int. Epiz 25 (2): 505-516. https://www.researchgate.net/publication/6702100_Livestock_production_systems_in_developin g_countries_Status_drivers_trends/link/0046352836c838f7f7000000/download

Castro-Salas J. M. (2014) Introducción de genotipos forrajeros en el sur del estado de México: análisis de crecimiento, composición química y valor nutritivo. Tesis Maestría y Doctorado. Universidad Autónoma del Estado De México. Toluca, Estado de México. 218 p.

Sevilla G. A.,A. Pasinato yJ. M. García (2001)Curvas de crecimiento de forrajeras templadas irrigadas. Archives of LatinAmerica Animal Production 9: 91-98.

Velasco Z.M.E., G. A. Hernández,H. V. A. Gonzales,P. J. Pérez,H. H. Vaquera yS. A. Galvis (2001)Curva de crecimiento y acumulación de estacional del pasto ovillo (Dactylisglomerata L.). Técnica Pecuaria en México 39 (1): 1-14.

https://cienciaspecuarias.inifap.gob.mx/index.php/Pecuarias/article/view/1338/1333

Wilson G.C.Y., G. A. Hernández,C. M. E. Ortega,C. C. López,G. R. Bárcena,R. J. L. Zaragoza y O. G. Aranda (2017) Análisis del crecimiento de tres líneas de cebada para producción de forraje, en el valle de México. Revista de la Facultad de Ciencias Agrarias UNCuyo 49(2): 79-92.

http://bdigital.uncu.edu.ar/objetos_digitales/9635/20172-cp06-wilson-garcia.pdf 